\title{
Analisis Pengaruh Diameter Kawat terhadap Distribusi Kapasitansi dari Wire Mesh Sensor: Studi Kasus Simulasi Sistem Deteksi Anomali pada Saluran Pembuangan Limbah Industri
}

\author{
Linahtadiya Andiani*, Amaliyah Rohsari Indah Utami
}

Universitas Telkom, Jl. Telekomunikasi No. 1, Terusan Buahbatu, Bandung 40257 Indonesia

*Email : linahtadiyaa@gmail.com

(Diterima 22 Oktober 2021; Disetujui 5 Desember 2021; Dipublikasikan 29 Desember 2021)

\begin{abstract}
Abstrak
Pembuangan limbah industri menjadi salah satu penyebab pencemaran lingkungan. Deteksi dini saluran pembuangan menggunakan sistem wire mesh sensor (WMS) dapat diterapkan dalam mencegah pencemaran lingkungan. WMS adalah sensor berbasis tomografi yang menghasilkan suatu citra distribusi dari suatu aliran fluida. Citra distribusi tersebut merupakan pola distribusi kapasitansi yang terukur oleh elektroda sensor. Tujuan dari penelitian ini adalah untuk mengetahui pengaruh diameter kawat terhadap kinerja sistem dalam mendeteksi anomali pada saluran pembuangan limbah. Pada penelitian ini, sistem WMS disimulasikan di dalam phantom silinder sebagai model dari pipa pembuangan limbah. Selain itu, suatu anomali bola juga ditambahkan sebagai representasi dari limbah padat yang akan dideteksi oleh sistem. Dari hasil simulasi, dilakukan analisis terlebih dahulu pada pola distribusi potensial listrik untuk mengetahui karakteristik potensial listrik dari sistem WMS yang dimodelkan. Ditemukan bahwa perbedaan parameter berupa variasi jenis larutan dapat mempengaruhi distribusi potensial listrik. Hal ini disebabkan adanya perbedaan nilai konstanta dielektrik masing-masing jenis larutan. Kinerja sistem WMS dalam mendeteksi anomali dievaluasi dengan menganalisis perubahan distribusi kapasitansi terhadap pengaruh perubahan diameter kawat. Hasil simulasi menunjukkan bahwa jenis fluida pada kondisi tanpa dan dengan anomali dapat dibedakan dengan jelas melalui pola distribusi kapasitansi yang terukur untuk seluruh diameter kawat. Diameter kawat hanya mempengaruhi kualitas citra distribusi.
\end{abstract}

Kata kunci: Diameter kawat, distribusi kapasitansi, wire mesh sensor

\section{Latar Belakang}

Limbah industri menjadi salah satu penyebab utama meningkatnya pencemaran lingkungan[1]. Pencemaran lingkungan akibat revolusi industri menjadi masalah utama yang dihadapi dunia saat ini. Sebagian besar limbah industri yang dibuang ke udara, air, dan tanah tanpa pengelolaan yang tepat akan menimbulkan dampak kesehatan yang serius melalui pencemaran udara, air, dan tanah[2].

Berdasarkan standar pengelolaan limbah yang tepat, salah satu upaya yang dapat dilakukan untuk mencegah pencemaran limbah berbahaya adalah deteksi dini pada saluran air yang terhubung dengan sistem pembuangan limbah industri[3]. Saat ini penerapan teknologi monitoring sebagai sistem pendeteksi pencemaran limbah menjadi komponen utama dalam pengelolaan limbah[4]. Teknik wire mesh sensor (WMS) merupakan teknik pencitraan yang bersifat intrusif [5] yang dapat diterapkan dalam sistem pendeteksian limbah industri.
Sistem WMS merupakan sistem sensor tomografi berbentuk wire mesh yang dirancang untuk pengukuran fraksi ruang kosong di dalam sistem gas-cair[6]. Hasil pengukuran fraksi berupa citra distribusi ruang kosong yang terukur dalam suatu aliran multifase. Aliran multifase yang dimaksud berupa campuran dua atau lebih fluida yang berbeda secara fisik[7]. Prinsip kerja WMS didasarkan pada pengukuran dari sifat kelistrikan fluida, yaitu konduktivitas dan permitivitas atau konstanta dielektrik. Dengan demikian parameter turunan dari aliran dapat diperoleh dari sifat listrik tersebut[8].

Metode kelistrikan yang bergantung pada perbedaan permitivitas atau konduktivitas antara fase fluida juga dapat digunakan untuk menentukan adanya rongga. Penerapan ini dapat berupa sebuah probe tunggal, seperti probe optik, sel konduktansi yang terdapat dalam pipa atau penerapan metode intrusif lainnya yang mampu melakukan pencitraan tomografi secara langsung dengan membentuk kisi- 
kisi titik deteksi yang memungkinkan rekonstruksi secara penuh pada daerah fraksi rongga[9].

Untuk sistem monitoring pada sistem pembuangan limbah dapat digunakan konstruksi sensor WMS yang terdiri dari dua lapisan, yaitu transmitter dan receiver. Kawat transmitter diposisikan $90^{\circ}$ relatif terhadap kawat receiver. Posisi transmitter dan receiver dipisahkan secara aksial dengan suatu jarak tertentu. Pada pengukuran pertama, salah satu elektroda transmitter sebagai elektroda aktif dikenai sinyal listrik yang tidak terhantar secara langsung pada lapisan receiver akibat adanya jarak pemisah antar lapisan tersebut. Sedangkan elektroda transmitter lainnya bertindak sebagai elektroda pasif yang dihubungkan dengan ground. Sinyal listrik akan diterima oleh masing-masing receiver dan diolah dalam proses rekonstruksi citra[10].

Perkembangan sistem sensor ini masih tergolong baru sehingga analisis jenis fluida yang dideteksi dan penerapannya masih sangat terbatas. Penerapan sistem WMS telah berhasil dikembangkan pada beberapa sistem deteksi, seperti sistem deteksi campuran minyak dengan air di dalam pipa kilang minyak lepas pantai [11], sistem deteksi termal surya pada pembangkit tenaga uap[12], dan sistem investigasi aliran multifase pada saluran pipa horizontal[13]. Selain penerapan sensor pada sistem deteksi, terdapat penerapan lainnya sebagai sistem pengukuran kuat medan listrik yang dapat mencitrakan pola persebaran medan listrik pada suatu bahan[14]. Peningkatan performansi sistem WMS juga telah dilakukan melalui analisis pengaruh parameter desain geometri sensor, seperti jarak kawat [15] dan jarak antar lapisan [16]. Dari hasil penelitian sebelumnya, masih harus dilakukan pengujian terhadap parameter desain yang lainnya, seperti diameter kawat.

Penelitian ini dilakukan untuk mengetahui performansi sistem WMS $16 \times 16$ yang diterapkan di dalam sistem pembuangan limbah industri. Performansi sistem dalam mendeteksi anomali didasarkan pada hasil analisis pengaruh diameter kawat sebagai parameter desain geometri sensor terhadap distribusi kapasitansi yang terukur. Metode analisis dilakukan secara simulasi menggunakan perangkat lunak.

\section{Metodologi}

Distribusi kapasitansi pada model sistem pembuangan limbah industri yang dihasilkan dari sistem WMS 16×16 telah disimulasikan menggunakan COMSOL Multiphysics dan Matlab. Metode penelitian diuraikan dalam 3 bagian, yaitu pemodelan, simulasi, dan rekonstruksi citra.

\section{A Pemodelan}

Bagian pemodelan ini terdiri dari 2 tahap, yaitu pengaturan parameter model geometri dan perancangan desain geometri. Model geometri yang dirancang pada penelitian ini berupa geometri pipa pembuangan dan elektroda WMS. Untuk parameter model geometri pipa pembuangan digunakan phantom berbentuk tabung dengan ukuran diameter dalam $13 \mathrm{~cm}$, diameter luar $14 \mathrm{~cm}$, dan panjang $10 \mathrm{~cm}$.

Untuk geometri elektroda WMS $16 \times 16$ diberikan ukuran panjang $15 \mathrm{~cm}$ pada setiap kawat dan variasi diameter kawat sebesar $0,1 \mathrm{~cm}, 0,3 \mathrm{~cm}$, dan $0,5 \mathrm{~cm}$ dengan jarak antar kawat sebesar 0,8 $\mathrm{cm}$. Sistem elektroda wire mesh terdiri dari dua panel, yaitu panel transmitter dan panel receiver seperti pada Gambar 1. Kedua panel tersebut dipisahkan dengan jarak 0,2 cm.

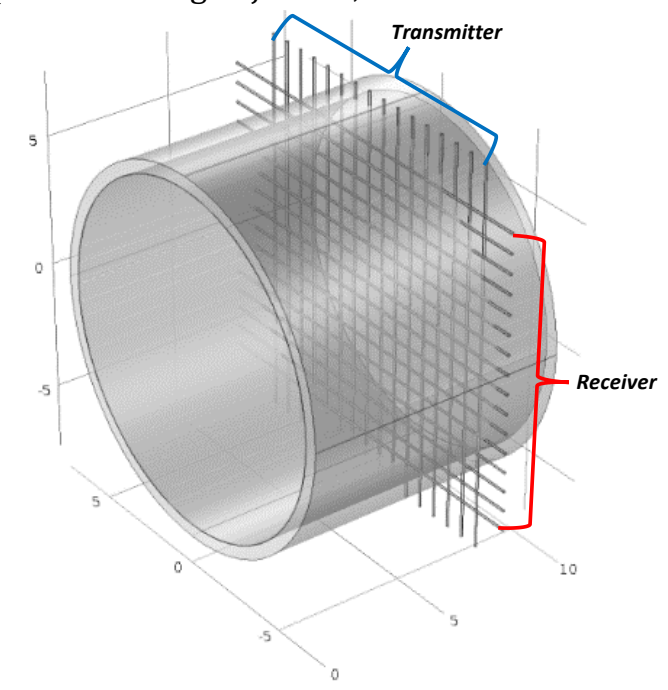

Gambar 1. Model geometri pipa pembuangan dengan elektroda wire mesh $16 \times 16$.

\section{B Simulasi}

Pada bagian ini dilakukan tahap simulasi melalui pendekatan hukum elektrostatis pada geometri yang telah dimodelkan menggunakan perangkat lunak COMSOL Multiphysics. Tahap simulasi terdiri dari pengaturan parameter fisika, proses komputasi, dan pengukuran parameter keluaran. Tabel 1 menunjukkan set parameter simulasi yang diterapkan dalam penelitian ini.

Pada pengaturan parameter fisika, parameter yang diatur meliputi parameter subdomain, boundary, mesh, dan solver. Parameter fisika yang 
POSITRON Vol. 11, No. 2 (2021), Hal. 104 - 111

diatur harus disesuaikan dengan kondisi asli dari sistem.

Tabel 1. Parameter simulasi

\begin{tabular}{|l|l|}
\hline \multicolumn{1}{|c|}{ Parameter } & \multicolumn{1}{c|}{ Set } \\
\hline Subdomain & $\begin{array}{l}\text { 1. Pipa pembuangan (PVC) } \\
\text { 2. WMS (tembaga) }\end{array}$ \\
& $\begin{array}{l}\text { 3. Fluida (air dan udara) } \\
\text { 4. Anomali (nikel) }\end{array}$ \\
\hline Boundary & $\begin{array}{l}\text { Terminal } \\
\text { 1. Kawat 1-16 (terminal 1-16) } \\
\text { 2. Kawat 17-32 (terminal 1-16) }\end{array}$ \\
\hline Mesh & Normal \\
\hline Solver & Electronics (Ec) \\
\hline Physical Study & Stationary \\
\hline
\end{tabular}

Tahap pengaturan parameter subdomain meliputi penentuan jenis bahan dan parameter fisika yang digunakan. Pada penelitian ini, bahan yang digunakan untuk elektroda wire mesh sensor adalah tembaga. Proses simulasi geometri pipa pembuangan dilakukan pada kondisi homogen dan inhomogen. Pada kondisi homogen digunakan variasi fluida sebagai isi pipa pembuangan, yaitu udara dan air. Sedangkan pada kondisi inhomogen diletakkan sebuah anomali berbentuk bola dengan ukuran diameter $4 \mathrm{~cm}$ dan berbahan elektrolit seperti pada Gambar 2. Pada simulasi ini dikondisikan bagian luar pipa adalah ruang udara.

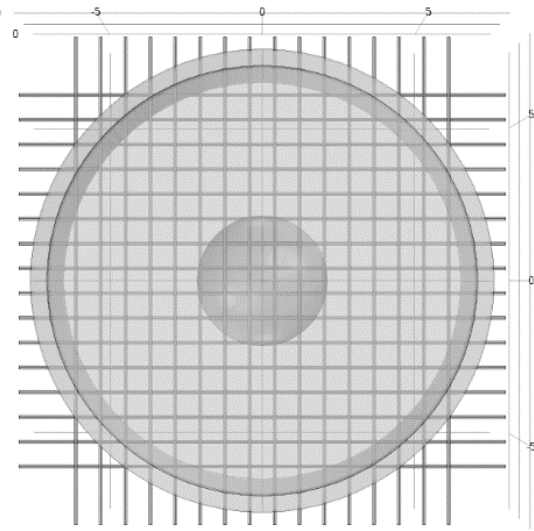

Gambar 2. Desain geometri pipa pembuangan dengan elektroda wire mesh sensor $16 \times 16$ untuk kondisi inhomogen.

Parameter fisika yang digunakan adalah konstanta dielektrik bahan seperti pada Tabel 1.

Tabel 2. Parameter fisika untuk pengaturan subdomain

\begin{tabular}{|c|c|}
\hline Bahan & Konstanta Dielektrik \\
\hline PVC & 2.9 \\
\hline Udara & 1 \\
\hline Air & 80 \\
\hline Tembaga & 1 \\
\hline Nikel & 12 \\
\hline
\end{tabular}

Tahap pengaturan boundary dilakukan untuk memberikan batasan pada elektroda kapasitif geometri yang berupa elektroda wire mesh sensor. Pada tahap ini dilakukan pembagian terminal elektroda yang bertindak sebagai transmitter dan receiver seperti pada Gambar 3. Untuk satu terminal transmitter aktif akan diberikan tegangan masukan sebesar $5 \mathrm{~V}$ sedangkan terminal transmitter lainnya akan bertindak pasif atau dikoneksikan dengan ground.

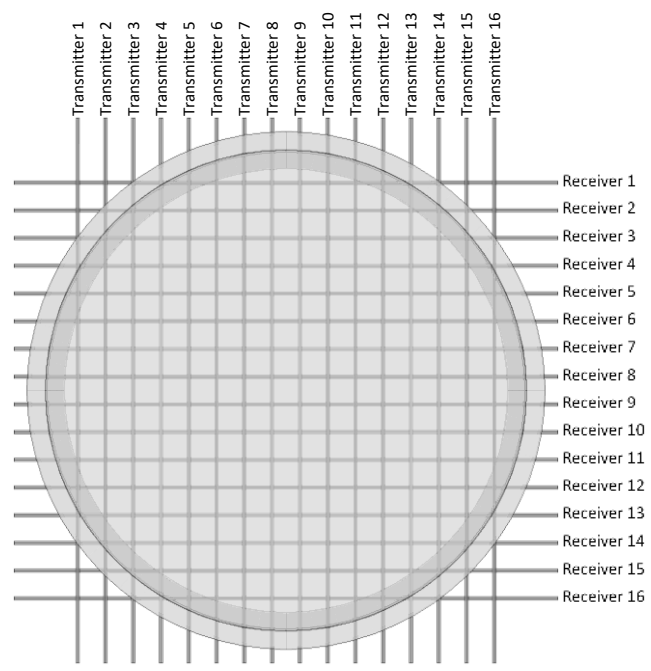

Gambar 3. Pembagian terminal pada elektroda wire mesh sensor $16 \times 16$

Tahap pengaturan parameter mesh dilakukan untuk mengatur parameter mesh. Parameter ini akan mempengaruhi keakuratan dari data simulasi yang didapat. Simulasi pada penelitian ini menggunakan ukuran normal sebagai free mesh parameter seperti pada Gambar 4.

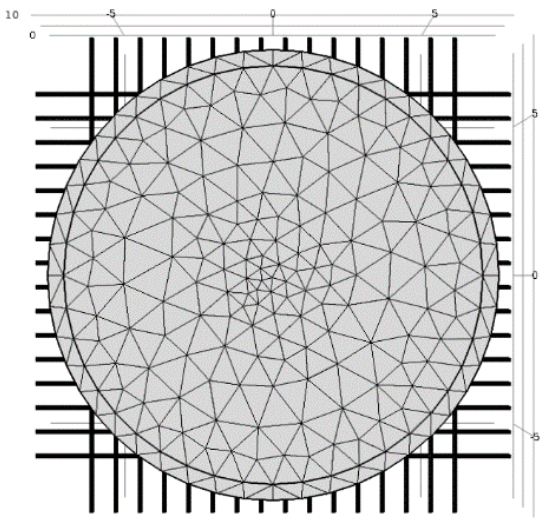

Gambar 4. Bentuk dari normal mesh pada desain geometri pipa pembuangan dengan elektroda wire mesh sensor $16 \times 16$.

Pada tahap pengaturan parameter solver digunakan pengaturan parameter uji berupa komponen physics dan komponen study. Tujuan 
simulasi pada penelitian ini adalah mendapatkan data distribusi kapasitansi melalui pendekatan konsep medan listrik sehingga digunakan pengaturan elektrostatik sebagai parameter physics. Sedangkan untuk parameter study yang digunakan sebagai parameter solver adalah stationary. Model matematis yang diterapkan dalam parameter ini adalah hukum Gauss (Persamaan 1) dan persamaan hubungan antara kapasitansi dengan konstanta dielektrik suatu bahan (Persamaan 2).

$$
\begin{aligned}
& \mathrm{E}=-\nabla \mathrm{V} \\
& \mathrm{C}=\frac{\mathrm{k} \varepsilon_{0} \mathrm{~A}}{\mathrm{~d}}
\end{aligned}
$$

Dengan $E$ adalah medan listrik $(\mathrm{V} / \mathrm{m}), V$ adalah potensial listrik (V), $C$ adalah kapasitansi (F), $k$ adalah konstanta dielektrik, $\varepsilon_{0}$ adalah permitivitas ruang hampa, $A$ adalah luas permukaan kawat $\left(\mathrm{m}^{2}\right)$, dan $d$ adalah jarak antar panel (m).

Setelah seluruh parameter fisika diatur, dilakukan tahap pemecahan masalah dari parameter yang telah diberikan melalui proses komputasi pada perangkat lunak. Apabila tidak didapatkan suatu error maka proses komputasi dapat dikatakan telah berhasil.

Tahap terakhir adalah pengukuran parameter keluaran berupa citra distribusi potensial listrik dan nilai kapasitansi pada setiap receiver. Untuk citra distribusi potensial listrik didapat dari 2 sampel kondisi, yaitu ketika terminal transmitter 1 dan terminal transmitter 8 dikondisikan aktif. Sedangkan untuk pengukuran nilai kapasitansi perlu dilakukan proses komputasi secara berulang untuk setiap pergantian transmitter yang bertindak sebagai elektroda aktif. Proses pengulangan yang dilakukan menerapkan konsep iterasi menggunakan perangkat lunak Matlab. Dari hasil iterasi untuk sistem WMS 16×16 didapat 256 data kapasitansi.

\section{C Visualisasi Data}

Setelah tahap simulasi, dilakukan pembuatan citra distribusi kapasitansi sebagai forward model melalui pengolahan data kapasitansi yang didapat dari simulasi. Data kapasitansi tersebut merupakan data pada titik perpotongan antara terminal transmitter aktif dengan masing-masing terminal receiver yang diukur. Dilakukan penggabungan data untuk seluruh kondisi menggunakan Matlab. Pada tahap ini setiap data kapasitansi dimasukkan ke dalam array 2 dimensi sesuai dengan posisi titik perpotongannya.

\section{Hasil dan Pembahasan}

\section{A Karakteristik Potensial Listrik Wire Mesh Sensor}

Untuk mengetahui karakteristik potensial listrik yang dihasilkan oleh sistem WMS pada geometri homogen dari pipa pembuangan limbah industri dilakukan simulasi dengan variasi fluida sebagai isi pipa pembuangan. Pada simulasi ini, terminal transmitter 1 dikondisikan aktif dengan tegangan masukan $5 \mathrm{~V}$ dan terminal lainnya dikondisikan pasif. Distribusi potensial listrik yang ditinjau berdasarkan potongan penampang bidang berbagai sumbu ditunjukkan pada Gambar 5 .

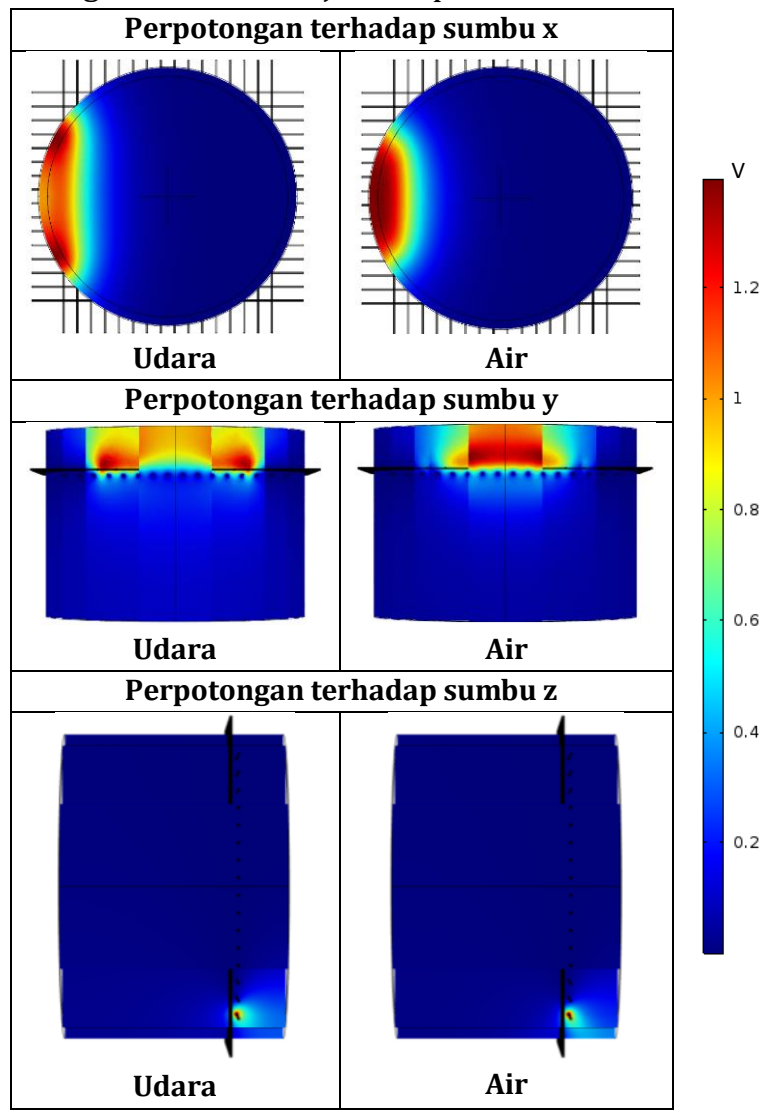

Gambar 5. Distribusi potensial listrik sistem wire mesh sensor pada geometri homogen dari pipa pembuangan limbah industri untuk fluida pengisi berupa udara dan air.

Pada studi ini dilakukan analisis distribusi potensial listrik setiap daerah yang ditinjau dari berbagai sisi tampilan penampang. Perbandingan dari ketiga sisi tampilan penampang dilakukan untuk mengetahui potongan penampang terbaik dalam menampilkan distribusi potensial listrik. Dari analisis perbandingan tersebut terlihat bahwa potongan penampang sumbu x dapat menampilkan perbedaan distribusi potensial listrik setiap daerah secara jelas dibandingkan posisi penampang 
lainnya. Hasil ini yang digunakan untuk analisis distribusi potensial listrik pada studi berikutnya.

Untuk analisis distribusi potensial listrik sistem WMS didapat bahwa daerah dengan potensial listrik tinggi yang ditampilkan dalam warna merah tua dengan kisaran nilai di atas $1 \mathrm{~V}$ berada di dekat elektroda transmitter aktif. Sedangkan daerah dengan potensial listrik rendah yang ditampilkan dalam warna biru tua dengan kisaran nilai kurang dari 0,2 $\mathrm{V}$ berada jauh dengan elektroda aktif. Pola distribusi potensial listrik ini sama dengan hasil yang didapat oleh Lee (2021) dalam analisis distribusi potensial listrik sistem WMS menggunakan Ansys[17]. Secara teori, hasil ini sesuai dengan konsep hukum Coulomb mengenai keterkaitan antara jarak suatu daerah terhadap elektroda aktif.

Berdasarkan analisis distribusi potensial listrik yang dihasilkan oleh sistem WMS juga didapat bahwa fluida pengisi pipa pembuangan limbah industri dapat mempengaruhi besar potensial listrik. Sifat kelistrikan fluida berupa konstanta dielektrik menjadi parameter utama yang mempengaruhi distribusi potensial listrik. Daerah dengan potensial listrik tinggi pada fluida udara lebih lebar dibandingkan pada fluida air. Hal ini sesuai dengan konsep medan listrik dan kapasitansi.

\section{B Analisis Pengaruh Anomali terhadap Distribusi Potensial Listrik}

Pada penelitian ini dilakukan pula analisis perbandingan distribusi potensial listrik antara kondisi homogen dengan kondisi inhomogen di dalam geometri pipa pembuangan. Analisis ini dilakukan untuk mengetahui pengaruh peletakan anomali di dalam geometri pipa pada kondisi inhomogen terhadap distribusi potensial listrik yang dihasilkan oleh sistem WMS. Pada penelitian ini digunakan nikel sebagai parameter bahan anomali karena menjadi salah satu senyawa berbahaya yang terdapat di dalam limbah industri.

Untuk analisis pada kondisi homogen dan inhomogen dilakukan simulasi untuk terminal transmitter 8 yang dikondisikan aktif dengan tegangan masukan $5 \mathrm{~V}$ dan terminal lainnya dikondisikan pasif. Pemilihan terminal ini disesuaikan dengan posisi anomali di dalam geometri pipa. Dari simulasi ini didapat distribusi potensial listrik untuk kondisi homogen dan inhomogen.

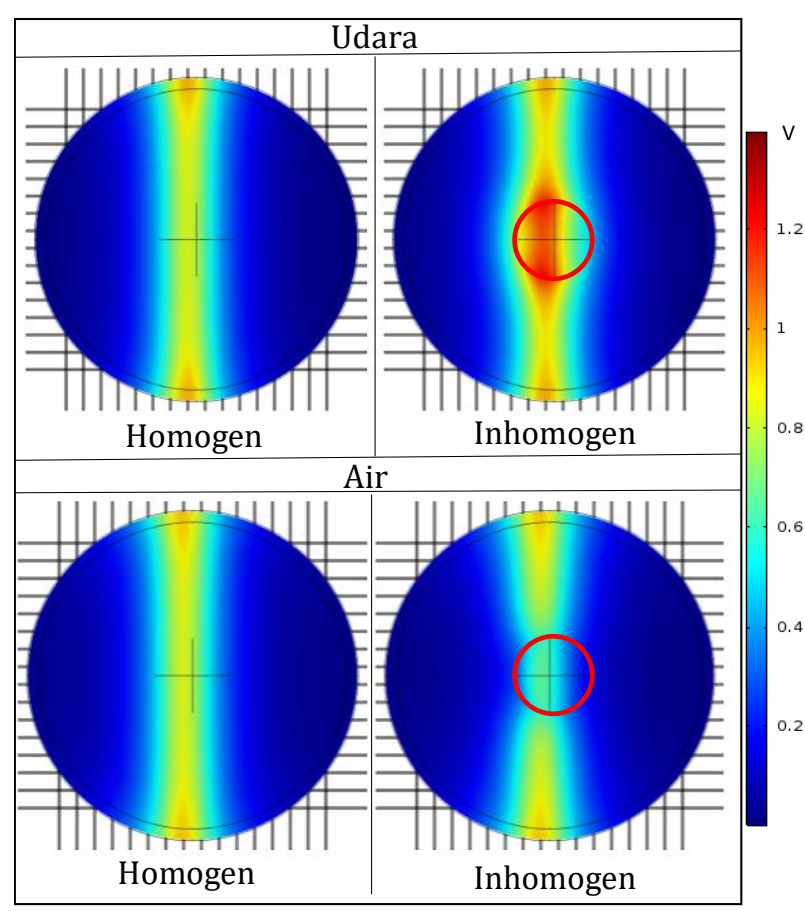

Gambar 6. Distribusi potensial listrik sistem wire mesh sensor pada kondisi homogen dan inhomogen dari pipa pembuangan limbah industri untuk fluida pengisi berupa udara dan air dengan anomali.

Pada Gambar 6 ditampilkan potongan penampang terhadap sumbu $\mathrm{x}$ dari distribusi potensial listrik pada kondisi homogen dan inhomogen. Untuk kondisi homogen didapat perbedaan hasil dari studi sebelumnya dikarenakan pada studi ini dikondisikan terminal transmitter 8 aktif sedangkan terminal lain pasif. Seperti pada analisis hasil simulasi sebelumnya, nilai potensial listrik tinggi berada pada daerah yang dekat dengan elektroda transmitter aktif dan nilai potensial listrik rendah berada pada daerah yang jauh dengan elektroda transmitter aktif. Tanda lingkaran merah pada tampilan distribusi potensial listrik untuk kondisi inhomogen menunjukkan posisi anomali di dalam geometri pipa pembuangan.

Dari analisis perbandingan distribusi potensial listrik pada kondisi homogen dan inhomogen diketahui bahwa anomali dapat mempengaruhi distribusi potensial listrik yang dihasilkan oleh sistem WMS. Hal ini ditunjukkan melalui perubahan pola distribusi potensial listrik di daerah sekitar anomali. Untuk medium udara terjadi peningkatan nilai potensial listrik di dalam anomali dan sekitar anomali. Sedangkan untuk medium air terjadi penurunan nilai potensial listrik di dalam anomali. Hal ini berkaitan dengan perbandingan konstanta dielektrik antara dua fluida pengisi. Sesuai pada 
Tabel 2 diketahui bahwa konstanta dielektrik dari nikel lebih besar dibandingkan udara dan lebih kecil dibandingkan air. Hasil simulasi ini sesuai dengan penjelasan yang telah disampaikan oleh Tompkins mengenai sifat kelistrikan fluida yang dapat mempengaruhi potensial listrik yang dihasilkan oleh elektroda WMS[9]. Secara teori elektrostatis, perubahan distribusi potensial listrik diakibatkan oleh pengaruh besar konstanta dielektrik dari anomali terhadap medan listrik yang dipancarkan oleh elektroda WMS aktif melalui suatu medium penghantar.

\section{C Analisis Pengaruh Diameter Kawat terhadap Distribusi Kapasitansi}

Setelah dilakukan analisis karakteristik potensial listrik dari simulasi sistem WMS yang telah dimodelkan maka dilanjutkan dengan analisis performansi sistem. Untuk mengetahui performa sistem WMS dalam mendeteksi anomali di dalam pipa pembuangan limbah industri maka dilakukan analisis pengaruh diameter kawat terhadap distribusi kapasitansi. Pada bagian analisis ini, dilakukan tahap simulasi dan visualisasi data. Hasil pengukuran nilai kapasitansi tiap receiver yang didapat dari simulasi divisualisasikan dalam bentuk citra distribusi kapasitansi sebagai forward model[5]. Dilakukan perbandingan hasil citra distribusi kapasitansi untuk variasi diameter kawat sebesar 0,1 cm, 0,3 cm, dan 0,5 cm pada kondisi homogen dan inhomogen seperti pada Gambar 7.
Pemilihan diameter disesuaikan dengan dimensi model pipa yang digunakan.

Gambar 7 menunjukkan citra distribusi kapasitansi yang merupakan visualisasi dari nilai kapasitansi tiap titik persilangan WMS untuk masing-masing kondisi pengukuran. Dari simulasi yang telah dilakukan didapat perbedaan nilai kapasitansi rata-rata pada setiap kondisi pengukuran. Nilai kapasitansi rata-rata untuk fluida udara sebesar 11,1 pF, fluida air sebesar 806 pF, dan anomali nikel sebesar 192 pF. Dari hasil tersebut diketahui bahwa pemberian fluida air akan menghasilkan nilai kapasitansi yang lebih besar dibandingkan dengan fluida udara. Secara teori kapasitansi, perbedaan nilai kapasitansi ini dapat dipengaruhi oleh sifat kelistrikan suatu bahan. Pada studi ini sifat kelistrikan bahan yang dijadikan parameter adalah konstanta dielektrik. Sesuai dengan persamaan (2) didapat bahwa hubungan kapasitansi dengan konstanta dielektrik adalah berbanding lurus. Berdasarkan perbandingan konstanta dielektrik antara fluida udara, air, dan nikel didapat bahwa udara memiliki nilai konstanta dielektrik paling kecil sedangkan air memiliki nilai konstanta dielektrik paling besar.

Dari analisis pola warna dari citra distribusi kapasitansi didapat bahwa terdapat perbedaan pola warna yang dihasilkan setiap kondisi. Diketahui bahwa pola warna yang ditampilkan pada citra berasal dari nilai kapasitansi yang terukur pada setiap titik persilangan. Untuk

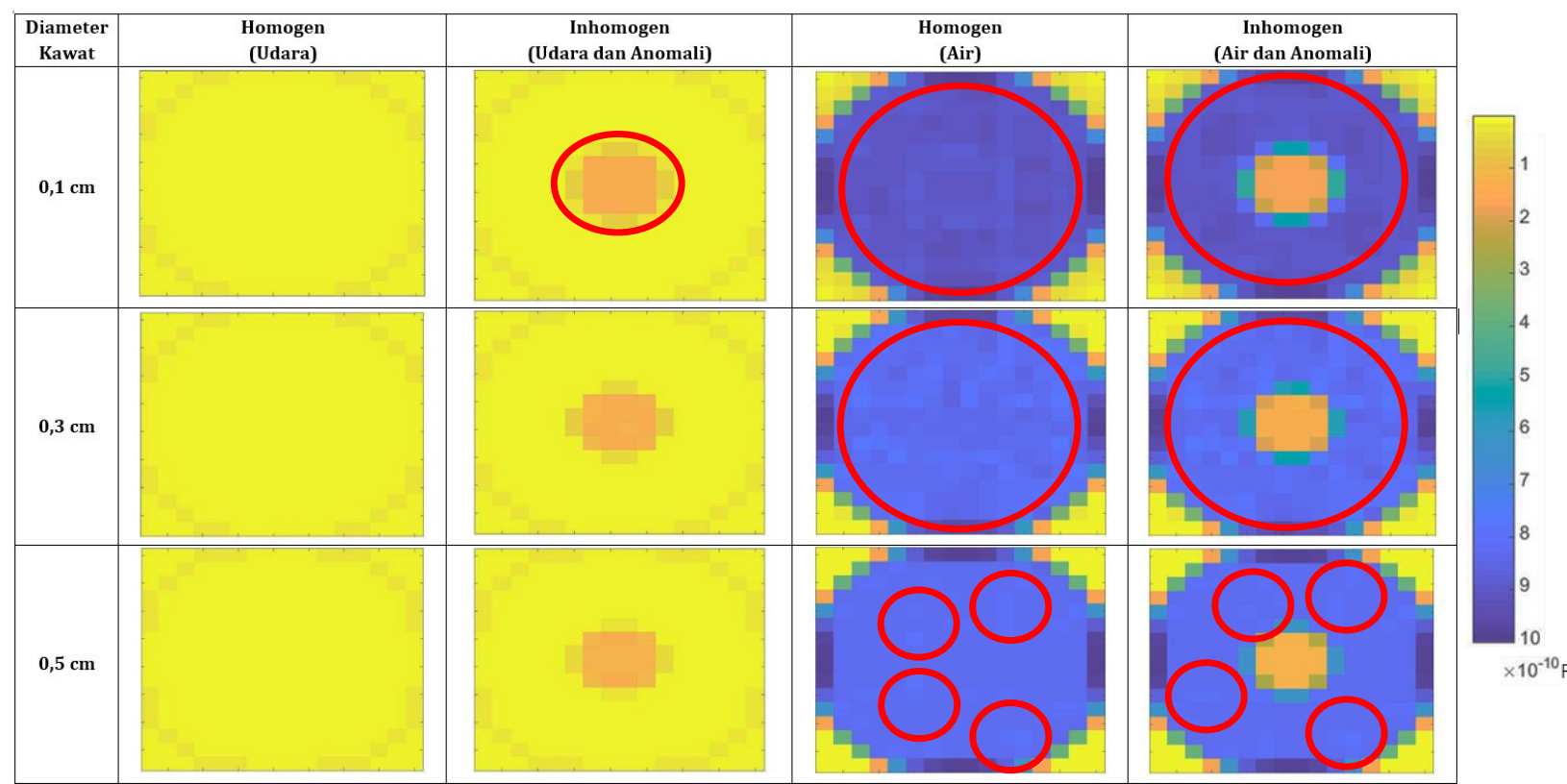

Gambar 7. Distribusi kapasitansi yang didapat dari pengukuran menggunakan sistem WMS dengan variasi diameter untuk kondisi homogen dan inhomogen. 
distribusi kapasitansi dari fluida udara divisualisasi dalam pola berwarna kuning, sedangkan distribusi kapasitansi dari fluida air divisualisasi dalam pola berwarna biru. Untuk distribusi kapasitansi dari anomali berbahan nikel divisualisasi dalam pola berwarna jingga. Apabila ditinjau dari rentang warna yang ditampilkan, didapat bahwa kapasitansi dari fluida udara lebih kecil dibanding kapasitansi dari anomali nikel dan fluida air. Hasil ini sesuai dengan penjelasan pada pembahasan sebelumnya.

Dari analisis pola warna didapat pula pola berwarna kuning pada sudut citra untuk seluruh kondisi yang menunjukkan bahwa pengukuran kapasitansi pada titik-titik persilangan tersebut terjadi di luar pipa. Sesuai yang telah dijelaskan pada bagian metodologi diketahui bahwa bagian luar pipa berupa ruang udara. Oleh karena itu, pola warna yang divisualisasikan sama dengan pola warna dari fluida udara.

Pada analisis citra distribusi kapasitansi kondisi homogen dan inhomogen untuk fluida pengisi berupa udara didapat pola lingkaran gelap yang dihasilkan dari pengukuran titik persilangan yang terdapat di dalam kulit pipa. Diketahui bahwa bahan pipa memiliki konstanta dielektrik yang lebih besar dibanding konstanta dielektrik udara. Oleh karena itu, didapatkan pola warna yang berbeda pada citra yang didapat.

Berdasarkan analisis pola warna dari citra distribusi kapasitansi didapat bahwa visualisasi nilai pengukuran kapasitansi dari sistem WMS dapat menampilkan perbedaan fluida yang terdapat di dalam pipa. Hal ini sesuai dengan konsep dasar sistem WMS yang telah disampaikan oleh Prasser dalam penelitiannya mengenai penerapan sistem WMS berbasis tomografi dalam mendeteksi aliran multifase[5].

Untuk analisis pengaruh diameter kawat terhadap distribusi kapasitansi didapat bahwa seluruh variasi diameter kawat yang diterapkan dalam sistem WMS dapat membedakan fluida dan mendeteksi anomali yang terdapat di dalam pipa. Namun jika dianalisis berdasarkan studi literatur dari hasil penelitian yang telah dilakukan oleh Dias mengenai resolusi citra dari sistem WMS didapat bahwa diameter kawat dapat mempengaruhi resolusi citra. Diketahui bahwa resolusi citra yang baik akan memiliki intrusive effect atau efek gangguan yang rendah[18]. Efek ini dapat berupa pola yang tidak merata dalam suatu citra seperti yang ditunjukkan oleh lingkaran merah pada Gambar 7. Dari hasil citra yang didapat dalam studi ini diketahui bahwa citra yang dihasilkan oleh sistem dengan diameter kawat 0,5 cm memiliki intrusive effect paling sedikit dibandingkan pada diameter kawat 0,1 dan 0,3 cm. Hal ini ditunjukkan dengan sedikitnya jumlah pola warna yang tidak merata pada citra yang dihasilkan oleh sistem dengan diameter $0,5 \mathrm{~cm}$ pada kondisi homogen dan inhomogen menggunakan fluida air. Sedangkan efek ini tidak terlihat pada kondisi homogen dan hanya terlihat sedikit di sekitar anomali pada kondisi inhomogen menggunakan fluida udara.

Dari analisis yang telah dilakukan didapat bahwa variasi diameter yang diterapkan dalam sistem WMS tidak berpengaruh pada performa sistem dalam membedakan fluida dan mendeteksi anomali. Dalam studi ini variasi diameter dapat mempengaruhi kualitas citra yang dihasilkan. Semakin besar diameter kawat yang digunakan maka semakin berkurang intrusive effect yang dihasilkan pada citra.

\section{Kesimpulan}

Dari penelitian ini, sistem WMS telah berhasil disimulasikan di dalam phantom silinder sebagai model dari pipa pembuangan limbah. Selain itu, suatu anomali bola juga ditambahkan sebagai representasi dari limbah padat yang akan dideteksi oleh sistem. Berdasarkan analisis pola distribusi potensial listrik yang didapat dari simulasi, ditemukan bahwa perbedaan parameter berupa variasi jenis larutan dapat mempengaruhi distribusi potensial listrik. Hal ini disebabkan adanya perbedaan nilai konstanta dielektrik masing-masing jenis larutan. Kinerja sistem WMS dalam mendeteksi anomali dievaluasi dengan menganalisis perubahan distribusi kapasitansi terhadap pengaruh perubahan diameter kawat. Hasil simulasi menunjukkan bahwa jenis fluida pada kondisi tanpa dan dengan anomali dapat dibedakan dengan jelas melalui pola distribusi kapasitansi yang terukur untuk seluruh diameter kawat. Diameter kawat hanya mempengaruhi kualitas citra distribusi. Untuk penerapan perangkat keras sistem WMS $16 \times 16$ pada saluran pipa pembuangan limbah industri yang membutuhkan hasil kualitas citra yang baik akan mungkin untuk menggunakan diameter kawat yang lebih besar. 


\section{Daftar Pustaka}

[1] Godswill, A. C., Gospel, A. C., Otuosorochi, A. I. and Somtochukwu, I. V., Industrial And Community Waste Management: Global Perspective, American Journal of Physical Sciences, 1(1), pp.1-16, 2020.

[2] Kabir, M., Habiba, U. E., Iqbal, M. Z., Shafiq, M. and Farooqi, Z.-R., Industrial Pollution and Its Impacts on Ecosystem: A Review, Journal by Innovative Scientific Information \& Services Network, 17(2), pp. 1364-1372, 2020.

[3] Vadde, K. K., Wang, J., Cao, L., Yuan, T., McCarthy, A. J. and Sekar, R., Assessment of water quality and identification of pollution risk locations in Tiaoxi River (Taihu Watershed), China, Water (Switzerland), 10(2), 2018.

[4] Lemos, A. R., Emerging-Tech-Wastewater Treatment-Management, Journal of Chemical Information and Modeling, 53(9), pp.16891699, 2013.

[5] Prasser, H. M., Böttger, A. and Zschau, J., A new electrode-mesh tomograph for gas-liquid flows, Flow Measurement and Instrumentation, 9(2), pp.111-119, 1998.

[6] Ghoshal, P., Sinha, F., Sen, S., Das, G., and Das, P. K. In Development and Application of Wire Mesh Tomography for Gas-liquid Systems, 2008.

[7] Kipping, R., Brito, R., Scheicher, E. and Hampel, U., Developments for the Application of the Wire-Mesh Sensor in Industries, International Journal of Multiphase Flow, 85, pp.86-95, 2016.

[8] Dias, F. D. A., Wiedemann, P., Silva, M. J. da, Schleicher, E., and Hampel, U., Tuning Capacitance Wire-mesh Sensor Gains for Measurement of Conductive Fluids, Technisches Messen, 88(S1), pp.S107-S113, 2021.

[9] Tompkins, C., Prasser, H. M., and Corradini, M., Wire-mesh Sensors: A review of Methods and Uncertainty in Multiphase Flows Relative to Other Measurement Techniques, Nuclear Engineering and Design, 337, pp.205-220, 2018.

[10] Silva, M. J. da , Schleicher, E. , and Hampel, U., Capacitance Wire-mesh Sensor for Fast Measurement of phase fraction, Meas. Sci. Technol, 2245(18), 2007.
[11] Rodriguez, I. H., Peña, H. F. V., Riaño, A. B., Henkes, R. A. W. M. and Rodriguez, O. M. H., Experiments with a Wire-Mesh Sensor for Stratified and Dispersed Oil-Brine Pipe Flow, International Journal Of Multiphase Flow, 70, pp.113-125, 2014.

[12] Berger, M., Mokhtar, M., Zahler, C., Willert, D., Neuhäuser, A. and Schleicher, E., In Two-phase flow pattern measurements with a wire mesh sensor in a direct steam generating solar thermal collector, AIP Conference Proceedings, pp. 1-8, 2017.

[13] Yeng, L. L., Rahim, R. A., Rajan, N., Manaf, M. S., Hafiz, M., Rahiman, F., Ahmad, A., Yunus, Y., Ibrahim, S., Wahab, Y. A., Ramli, M. F., Ridzuan, S. and Abdullah, A. , Wire Mesh Tomography System for Horizontal Two-phase Fluid Flow Investigation, Journal of Electrical Engineering, 20(2), pp.42-48, 2021.

[14] Sujiwa, A., In Wire-Mesh $16 \times 16$ capacitance sensor for analysis of capacitance distribution on cylindrical pipe, IPTEK Journal of Proceedings Series, pp.130-135, 2018.

[15] Richter, S., Aritomi, M., Prasser, H. M. and Hampel, R., Approach Towards Spatial Phase Reconstruction in Transient Bubbly Flow using a Wire-mesh Sensor, International Journal of Heat and Mass Transfer, 45(5), pp.1063-1075, 2002.

[16] Shaban, H. and Tavoularis, S., Performance evaluation of conductivity wire-mesh sensors in vertical channels, Flow Measurement and Instrumentation, 54, pp.185-196, 2017.

[17] Lee, J. W., Heo, H., Sohn, D. K. and Ko, H. S., Development of a Numerical method for Multiphase Flows using an Electrostatic Model in a Wire-mesh Sensor, Engineering Applications of Computational Fluid Mechanics, 15(1), pp.344-362, 2021.

[18] Dias, F. de A., Increasing Image Resolution for Wire-Mesh Sensor Based on Statistical Reconstruction, Federal University of Technology, Curitiba, pp. 16-68, 2017. 